\title{
The BRAID Sharing Circle
}

$\mathrm{M}$ onday: As I did my morning rounds, Mr. Torsky codes on me. I start CPR, activate the trauma team and we work hard for 25 minutes. Mr. Torsky dies. Slightly out of breath, I peer down at this elderly man with his soft gentle face, eyes still open - eyes that will never see again. I look at his thin, wrinkled hands - his left thumb has a scar on it. A memory flickers - my dad had a scar like that. He got it on a fishing trip when I was seven. The hook went in his thumb instead of the bait. That was the trip I caught my first salmon. Dad was so proud.

I look calm on the outside - to the room peppered with nurses, residents and the occasional panic-stricken medical student. I catch one student's wide, scared eyes with my weathered, crowfoot lined ones. Despite my training, my experience, my seniority, I begin to think my eyes and the ones of the medical student have more in common than one would think. Despite my seemingly decisive, hard demeanor, I feel just as confused, lost and yes - scared - as that student in the corner. What is happening to me? I've led dozens of codes, seen many die. Why is seeing this man's thumb taking me back 50 years to some fishing trip, when I held Dad's hand for the last time? Why now? I blink back a few tears, turn away from the crowd and pretend that my pager is going off. I leave the room, avoiding all eyes, avoiding the growing hurt inside. I think it's been there a long time. I push it back down and head down the hallway. As I push the elevator button, I see a small white sign: BRAID (Believing we can Reduce All Incidence of Disease) Sharing Circle: A confidential peer-support group for medical students, residents and physicians. They meet tomorrow night. Maybe I'll go?

Tuesday: BRAID Sharing Circle. True to form, the chairs are arranged in a circle. Most seats have younger people in them - with varying levels of weariness

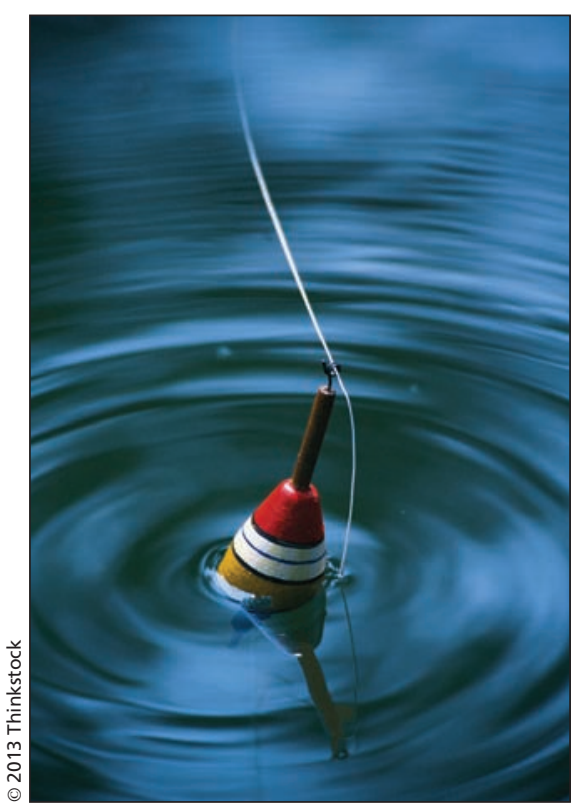

and anxiety on their faces. I am, by far, the oldest person in the room. I shift in my seat. What am I doing here? We finish getting our refreshments and take our seats. The organizer of the group welcomes us and sets the ground rules of the hour-long session: all that is said is confidential, no interrupting and no discussions until the group takes a break. Individuals can share or pass. We can talk about anything - work-related, home life, negative, positive - anything goes.

A fourth-year student starts. She talks about her insomnia. She worries about her exams, about her preceptors and about her husband who seems more distant than ever. She finishes, wiping a tear, and thanks us for listening. I shift in my chair. Distant spouse - I've been there. Married for 35 years, but my profession had taken its toll on us, on her. She's put up with a lot, and she's stayed with me. I don't think I've ever really thanked her for that.

The next chair is occupied by a timid-looking third-year medical student. I've got him pegged before he even starts talking. He's going to talk about how hard clerkship is and how he's terrified of failing. He starts by saying home and school are good. I look at him as he takes a long pause. With his head down, in a soft voice, he tells us that 10 years ago, today, his dad died in a fire. My heart starts beating faster. His dad died as he held his hand in intensive care. My heart opens a bit. Emotion seeps out and my eyes become wet. His dad died. My dad died. I haven't thought of dad for months, haven't cried for years. But here I sit, seeing the pain on this young man's face, and realize it mirrors my own. We both miss our dads.

Eventually my turn comes. I wasn't planning on saying anything. But my mind and heart are full of my dad right now. I tell them that I miss my dad, too. I look up, and see friendly, supportive eyes looking back at me. I'm encouraged. I let go and my mouth is talking before my mind can edit. I find myself talking about a fishing trip my dad took me on 30 years ago, and of how I caught my first salmon. After my story, which has us all smiling and laughing, I take a deep breath and feel better. It's been years since I've told that story. It's been years since I've let myself really feel the loss of my dad. My heart feels lighter as I settle in to listen to the next person's story.

The hour quickly passes, each of us having our turn to be heard. I feel rejuvenated, and I want to come back. Before I leave, I add BRAID Sharing Circle 5:00 pm to my calendar - in two weeks.

\section{Norry Kaler BSc MSc \\ Third-year medical student \\ Dalhousie University \\ Sharona Kaler BA MD \\ Family physician \\ Halifax, NS}

For more information on the BRAID Sharing Circle, see Appendix 1, available at www.cmaj.ca/lookup/suppl/doi:10.1503 /cmaj.121836/-/DC1

CMAJ 2013. DOI:10.1503/cmaj.121836 